\title{
CO2 Sequestration Potential of Texas Low-Rank Coals
}

\author{
Quarterly Technical Progress Report
}

Reporting Period Start Date: October 1, 2002

Reporting Period End Date: December 31, 2002

By:

\author{
Duane A. McVay \\ Walter B. Ayers, Jr. \\ Jerry L. Jensen
}

February 2003

\section{DE-FC26-02NT41588}

Texas Engineering Experiment Station 3000 TAMU

332 Wisenbaker Engineering Research Center

College Station, Texas 77843-3000 


\section{DISCLAIMER}

This report was prepared as an account of work sponsored by an agency of the United States Government. Neither the United States Government nor any agency thereof, nor any employees, makes any warrant, express or implied, or assumes any legal liability or responsibility for the accuracy, completeness, or usefulness of any information, apparatus, product, or process disclosed, or represents that its use would not infringe privately owned rights. Reference herein to any specific commercial product, process, or service by trade name, trademark, manufacturer, or otherwise does not necessarily constitute or imply its endorsement, recommendation, or favoring by the United States Government or any agency thereof. The views and opinions of authors expressed herein do not necessarily state or reflect those of the United States Government or any agency thereof. 


\begin{abstract}
The objectives of this project are to evaluate the feasibility of carbon dioxide $\left(\mathrm{CO}_{2}\right)$ sequestration in Texas low-rank coals and to determine the potential for enhanced coalbed methane (CBM) recovery as an added benefit of sequestration.

The main objectives for this reporting period were to work on Tasks 1 and 2, which consisted of the following subtasks: review literature on $\mathrm{CO}_{2}$ sequestration and the effect of $\mathrm{CO}_{2}$ injection on methane production from coalbeds; acquire information on power plant flue gas emissions; acquire data on Texas coal occurrences and properties and formation water quality; construct a digital base map; and select geographic areas and geologic formations for study.

Flue gas information, including volumes and compositions, were obtained for major Texas power plants and other industrial sources, such as cement plants. We evaluated and obtained computer mapping software and began building a digital base map that will be used to depict industrial emissions, coal occurrence, and water quality information. Digital data sets allow us to superpose data for visualization and for assessment of $\mathrm{CO}_{2}$ sequestration issues.
\end{abstract}




\section{TABLE OF CONTENTS}

DISCLAIMER

$\begin{array}{lll}\text { ABSTRACT } & \text { iii }\end{array}$

INTRODUCTION 1

EXPERIMENTAL 1

RESULTS AND DISCUSSION 1

CONCLUSION 2

REFERENCES 2 


\section{INTRODUCTION}

The main objective of this project is to investigate the feasibility of $\mathrm{CO}_{2}$ sequestration in Texas low-rank coals. For this reporting period, our objectives consisted of locating the major point sources of $\mathrm{CO}_{2}$ emissions, obtaining coal property (quality) information for Texas low-rank coals, and acquiring information on ground water properties. Protected aquifers and their limits must be known in order to ensure that they are not selected for $\mathrm{CO}_{2}$ injection. The locations of greenhouse gas emissions, as well as volumes and composition, are necessary to rank industrial sources and to assess their proximity to low-rank coals that may be used for sequestration.

\section{EXPERIMENTAL}

None.

\section{RESULTS AND DISCUSSION}

Large amounts of $\mathrm{CO}_{2}$ are produced by many industrial sources, primarily power plants, throughout Texas. We identified these major point sources of $\mathrm{CO}_{2}$ and began constructing a digital map. We obtained data such as the flue gas composition and the amounts of $\mathrm{CO}_{2}$ emitted on a yearly basis for each major source. We then compiled a table with source type, emission volumes, flue gas composition, and contact information for each major $\mathrm{CO}_{2}$ source.

Locations of freshwater aquifers and their limits are important considerations. Water salinity values must be known in order to inject at depths where the water is not protected. This information will be used to identify areas and depths where $\mathrm{CO}_{2}$ sequestration would be permitted for the Wilcox, Yegua, and Jackson low-rank coals. Once we have completed gathering information on $\mathrm{CO}_{2}$ emissions, coal properties, and hydrology, three sites will be chosen for a detailed investigation.

Mapping software packages were compared to see which would be the most effective. We selected the software and obtained the coordinates for county lines and major rivers that will be included in the maps.

We are compiling an annotated bibliography of technical papers and reports used in our investigation. Also, literature concerning other forms of $\mathrm{CO}_{2}$ sequestration was reviewed to assess the advantages and disadvantages and the technical issues common among the methods. Literature on gas sorption in coal, factors affecting gas-content distribution in coalbeds, and compositional variability and origins of coal gases was also reviewed. 


\section{CONCLUSION}

None at this time.

\section{REFERENCES}

None. 